\title{
The problems of developing infrastructure that ensures the economic security of small businesses in the agricultural sector (on the example of the Orenburg region)
}

\author{
Larisa Dobrodomova ${ }^{1, *}$, Vladimir Dzhoraev ${ }^{1}$, Lyubov Tutaeva ${ }^{1}$, Larisa Voroshilova $^{1}$, and \\ Elena Dmitrieva ${ }^{2}$ \\ ${ }^{1}$ FSBEI HO Orenburg State Agricultural University, 18, str. Chelyuskintzev, 460014, Orenburg, \\ Russia \\ ${ }^{2}$ FSBEI HO Orenburg State University, 13, Pobedy ave., 460018, Orenburg, Russia
}

\begin{abstract}
The article is devoted to the study of the problems of infrastructure developing that ensures the economic security of small and medium-sized entrepreneurship in the agro-industrial complex, the analysis of factors restricting the development of SMEs and their support institutions is carried out, measures to overcome the problems of developing the infrastructure ensuring the economic security of SMEs are proposed. Infrastructure development depends on the capabilities of SMEs, and the opportunities are due to the influence of the external environment. To assess the situation, a survey of agricultural entrepreneurs was conducted, and according its results entrepreneurs noted the most significant factors limiting the development of SMEs: difficult access to loans, external financing; lack of own funds for business development; taxation; strong competitors, etc. Among the problems that hinder the development of infrastructure were noted: the financial illiteracy of start-up entrepreneurs, the low level of entrepreneurial activity and the income received by SMEs, the disproportion in the distribution of support institutions across the Orenburg region and, as a result, their absence in remote areas and rural areas. To overcome these problems, the creation of institutions for training and retraining entrepreneurs and the "Business Center for Small and Medium Enterprises".
\end{abstract}

\section{Introduction}

A distinctive feature of entrepreneurial activity is that in an open competitive environment, business entities act at their own risk and peril, under their personal and, above all, property liability. Particularly high risks are pursued by small enterprises at the beginning of their activities. During the first 18 months, $50 \%$ of established enterprises cease to operate, and in 10 years only $10 \%$ remain of established enterprises [1, p. 21].

In the economic literature, the definition of "economic security" is given more often for

\footnotetext{
*Corresponding author: larisa-dobrodom@mail.ru
} 
large business structures and is reduced to the state of its protection from the negative impact of external and internal threats, destabilizing factors, which ensures the sustainable implementation of the main commercial interests and goals of statutory activity. Moreover, among the main external threats the following are considered: economic policy of the state; actions of other business entities; crises $[2,3,4,5]$. Unified approaches to determine small business economic security have not been developed. Small business features contain both pros and cons, which significantly affect its ability to ensure the sustainable development. Independent economic small businesses security in the agro-industrial complex is hard due to many reasons and without the development of infrastructure that would help small businesses in their sustainable development, the creation and growth of a business becomes unattractive $[2,6,7,8]$.

Infrastructure (from lat. Infra - below/under and structura - structure, location) is a term that appeared in the economic literature in the late 40 s of 20 century to denote the complex of economy sectors to serve industrial and agricultural production [9].

Therefore, infrastructure providing economic security for small businesses will be understood as a set of institutions that provide services to small businesses to reduce economic security threats or to minimize the negative consequences of their manifestation on a paid basis or as part of state support. One of the problems of development for SMEs in the agro-industrial complex is the territorial remoteness of institutions.

\section{Materials and Methods}

Inconsistency in the development of infrastructure to meet the contemporary demands can lead to degradation of relations or a significant decrease in the rate of their development, which is clearly illustrated by the example of the agro-industrial complex of the Republic of Kazakhstan in an article by Stukach V.F., Saparova G.K., Sultanova G.T., Saginova S.A. [10].

In the Orenburg region, this direction has been developed. In June 2019, Order No. 125 of March 14, 2019 of the Ministry of Economic Development of the Russian Federation "On Approving Requirements for the Implementation of Activities of the Subjects of the Russian Federation, whose budgets are provided with state subsidies to support small and medium-sized enterprises in the constituent entities of the Russian Federation in order to achieve their goals, indicators and results of regional projects, ensuring the achievement of the goals, indicators and results of federal projects that are part of the national project "Small and medium-sized enterprises and support for individual entrepreneurial initiatives", and requirements for organizations that form the infrastructure for supporting small and medium-sized enterprises "came into force $[11,12]$.

According to Art. 7 of the Law of the Orenburg Region "On the Development of Small and Medium Enterprises in the Orenburg Region" No. 3118 / 691-1U-OZ of September 29, 2009 , the development and implementation of programs for the development of small and medium enterprises is carried out by the authorized executive body of the Orenburg Region - the Ministry of Economic Development, industrial policy and trade of the Orenburg region .

Implementation of the activities of the subprogram "Development of small and mediumsized enterprises" of the state program "Economic development of the Orenburg region for 2014-2015 and for the long term to 2020" and the Decree of the Government of the Orenburg region dated 31.08.2012 No. 751-pp "Development of agriculture and regulation of agricultural markets of products, raw materials and foodstuffs of the Orenburg Region" for 2013-2020, as a rule, is carried out on a competitive basis by organizations supporting the infrastructure of small and medium-sized enterprises of the Orenburg region [13]. There is a regional fund for supporting small and medium-sized enterprises, a center of 
competence in the field of agricultural cooperation and support for farmers, the Orenburg business-incubator, a guarantee fund for small and medium-sized enterprises of the Orenburg region and other organizations that provide services to support small businesses.

However, there are problems in the development of infrastructure. One of the main problems that arise in the work with small businesses in the agro-industrial complex is the lack of reliable statistical data on the development of this economy segment.

For analysis, we used the data characterizing the development of small business in the regions of the Russian Federation as of May 2019, the source of which is the Federal Tax Service [14].

The information on the number of legal entities and individual entrepreneurs in the Orenburg region, which is contained in the Unified Register of Small and Medium Enterprises as of May 10, 2019 is given below in Table 1.

Table 1. Number of legal entities and individual entrepreneurs according to Unified Register of Small and Medium Enterprises (further SME) as 10.05.2019 (Orenburg region).

\begin{tabular}{|l|c|c|c|}
\hline \multirow{2}{*}{ Indicator name } & \multirow{2}{*}{ Total } & \multicolumn{2}{c|}{ Of them } \\
\cline { 3 - 4 } & & Legal entity & Individual entrepreneur \\
\hline Total & 59714 & 20930 & 38784 \\
\hline Having the sign "newly created" & 13242 & 2463 & 10779 \\
\hline Microenterprises & 57174 & 18700 & 38474 \\
\hline Small enterprises & 2354 & 2048 & 306 \\
\hline Medium enterprises & 186 & 182 & 4 \\
\hline
\end{tabular}

In just 2 years (from June 10, 2017 to May 10, 2019), the number of SMEs in the Orenburg Region is decreased by 1574 units (from 61,288 to 59,714 enterprises) or by $2.6 \%$.

This reduction was due to a decrease in the number of medium-sized enterprises by 2 enterprises (from 188 to 186 enterprises), small - by 102 enterprises (from 2456 to 2354 enterprises) and micro-enterprises - by 1470 units (from 58644 to 57174).

At the same time, if the number of SMEs operating in the status of individual entrepreneurs has changed insignificantly (an increase of 96 SMEs from 38688 in 2017 to 38784 in 2019), then the number of SMEs operating in the status of legal entity has decreased by 1670 SMEs or by $7,4 \%$.

For the last five years, the development of SMEs has been significantly affected by the adoption of a number of legislative acts $[15,16,17,18,19,20]$, as well as the following events and trends:

- the size of insurance premiums for IE has changed;

- business ombudsmen have appeared;

- accounting costs decreased;

- preferential privatization of rented premises was introduced;

- access of small business to government order was increased;

- patent tax system was introduced;

- tax control was toughened;

- property tax was raised;

- the definition of the tax base as the cadastral value of objects is being introduced;

IE insurance contributions to the FIU began to be divided into a fixed part and an

- individual part of insurance contributions to the PFR;

- the political situation has complicated, which led to the introduction of bilateral sanctions that limited the access of Russian companies to foreign capital, as well as access to a number of foreign markets, but this situation contributes to the realization of the potential for import substitution; 
- it is difficult to resist large organizations and associations that capture many attractive for SMEs agricultural markets;

- negative expectations intensified both in the development of the SME sector and the Russian economy as a whole, which is partially due to the expected increase in taxes.

\section{Results}

The main activity of the most infrastructure organizations is concentrated in the cities of the region, while rural municipalities remain out of their focus.

The reasons for such state of affairs are:

- firstly, the lack of financial resources to cover the entire area;

- secondly, in non-financial support forms (consultative, educational, informational) there is absence of constant solvent demand for these services especially in rural areas, which makes it impossible the functioning of infrastructure organizations on the basis of selfsufficiency, and municipal budgets cannot finance their activities.

The main problem in the development of the infrastructure for ensuring the economic security of small and medium-sized enterprises in the Orenburg region, in our opinion, is that the current system of institutions performs more the functions of state financial support of small and medium-sized enterprises and indirectly ensures their economic security. If the subject is not in the state program, then he does not receive support to ensure its safety.

Table 2. The main organizations of the infrastructure for ensuring the economic security of SMEs in the agro-industrial sector of the Orenburg region.

\begin{tabular}{|l|l|}
\hline \multicolumn{1}{|c|}{ Name of organization - infrastructure } & \multicolumn{1}{c|}{ Provided services } \\
\hline \multicolumn{1}{|c|}{ State and municipal organizations, as well as with state participation } \\
\hline $\begin{array}{l}\text { Non-profit micro-credit company "Orenburg } \\
\text { Regional Fund for Small Business Support", a } \\
\text { center of competence in the field of agricultural } \\
\text { cooperation and support for farmers }\end{array}$ & $\begin{array}{l}\text { Microcredit, guarantee fund for agricultural } \\
\text { consumer cooperatives; Information and } \\
\text { marketing services, etc .; Consulting support. }\end{array}$ \\
\hline $\begin{array}{l}\text { Non-governmental organization "Guarantee fund } \\
\text { for small and medium-sized enterprises of the } \\
\text { Orenburg region (micro-credit company)" }\end{array}$ & $\begin{array}{l}\text { Guarantee fund for region subjects of SMEs, } \\
\text { microcredit and consulting support. }\end{array}$ \\
\hline $\begin{array}{l}\text { Small Business Support Fund of the city of } \\
\text { Novotroitsk }\end{array}$ & Microcreditand consulting support \\
\hline $\begin{array}{l}\text { State Institution "Orenburg Regional Business } \\
\text { Incubator" }\end{array}$ & $\begin{array}{l}\text { Lease of office and production facilities at } \\
\text { preferential rates. }\end{array}$ \\
\hline MI "OrskBusinessIncubator" & $\begin{array}{l}\text { Lease of office and production facilities at } \\
\text { preferential rates. }\end{array}$ \\
\hline $\begin{array}{l}\text { Centers of consulting and legal SMEs support for } \\
\text { in municipalities of the region }\end{array}$ & $\begin{array}{l}\text { Information, marketing services, etc ;; } \\
\text { development of business plans, etc. }\end{array}$ \\
\hline \multicolumn{2}{|c|}{ Public organizations } \\
\hline $\begin{array}{l}\text { Commerce and Industry Chamber of the Orenburg } \\
\text { Region }\end{array}$ & $\begin{array}{l}\text { Information, marketing services; development of } \\
\text { business plans; support in the field of training, } \\
\text { retraining and improving the qualifications of } \\
\text { employees (conducting workshops). }\end{array}$ \\
\hline $\begin{array}{l}\text { All-Russian public organization of small and } \\
\text { medium-size enterprises "Russia OPORA" } \\
\text { Entrepreneurs (Employers) }\end{array}$ & $\begin{array}{l}\text { Information, marketing services; development of } \\
\text { business plans; support in the field of training, } \\
\text { retraining and improving the qualifications of } \\
\text { employees (conducting workshops). }\end{array}$ \\
$\begin{array}{l}\text { Informationsupport(information, marketing } \\
\text { services and others) }\end{array}$ \\
\hline
\end{tabular}


At present, a significant share of SMEs is comprised of novice small businesses with a market experience up to 1 year, operating more often in the format of microenterprises. This category of SMEs usually has minimal assets, small turnovers, unstable income, they work on simplified taxation systems and, as a result, there is a significant number of very different risks for SMEs and organizations interacting with them. These organizations fall out of the state support mechanisms, and hence from the service area of institutions of economic security infrastructure, although they are most ones in need.

Such SMEs have a strong need in a small working capital, which they cannot satisfy at the expense of bank capital due to the lack of collateral, financial opacity and the existing regulatory framework. Bank of Russia Regulation No. 254 on Reservation requires to createthe significant reserves for loans to start-up small businesses, that makes it unattractive for banks to lend to this category of business, and so government support is the only way to obtain financing for the development of their business [21].

One aspect of the problem is that there is a disproportion between the population and the number of small businesses in the regional center, Orenburg, and the rest of the region. The results of research conducted by the authors suggest that there is almost complete absence of systemic support of small businesses in most municipalities of the region (except the city of Orenburg) and the great need for such support.

It is recognized both by the SMEs in the agro-industrial complex themselves and by representatives of municipal governments.

This situation has developed for several reasons:

- deficiency of local budgets, leading to the lack of real mechanisms to support small

businesses at the municipal level;

- lack of state support consistency of small business, leading to inefficient spending of budget funds;

- "Personnelshortages"

duetothelackofspecialistsinmunicipalitiestrainedtoworkwithsmallandmedium-

sizedbusinesses;

- the impossibility of replacing in modern conditions the state infrastructure of support and developmentof entrepreneurship by a market one, since the infrastructure created by the regional authorities (for example, business centers) cannot be self-sustaining due to the market narrowness, the lack of sufficient solvent demand, and the lack of formation of the consulting services market;

- territorial remoteness from the regional center, leading to information insufficiency and inability to use state support mechanisms at the regional level due to high transportation costs.

Scientists and specialists comprehensively analyze the SMEs development problems [2, $6,22,23]$. The limiting factors in the development of the economic security infrastructure of small businesses include financial illiteracy of entrepreneurs, their lack of awareness of products and services. The second factor is the shadowing of small businesses, which makes it impossible to disclose complete information about the capabilities of the entrepreneur, and get competent service. The third factor is that any disclosure of information about their activities, which is mandatory for insurance, getting a loan from a commercial bank and other microfinance institutions, makes it a potential object of raider capture.

Let us analyze the factors that impede or limit business development in the Orenburg region based on a survey of entrepreneurs conducted as part of an on-site seminar on districts and cities of the region. The survey results on the most significant factors are presented below in Table 3 . 
Table 3. Factors that limit small and medium size business development in agro-industrial complex.

\begin{tabular}{|l|c|c|c|c|c|}
\hline \multicolumn{1}{|c|}{ Factor } & $\begin{array}{c}\text { Don't } \\
\text { limit }\end{array}$ & $\begin{array}{c}\text { Insignifi } \\
\text {-cantly }\end{array}$ & Medium & Highly & $\begin{array}{c}\text { Signifi- } \\
\text { cantly }\end{array}$ \\
\hline Taxation & 22.8 & 19.0 & 22.8 & 24.2 & 6.8 \\
\hline Strong competitors & 40.2 & 17.1 & 19.1 & 14.0 & 5.0 \\
\hline Lack of equity & 29.8 & 16.4 & 24.8 & 19.4 & 5.8 \\
\hline Lack of state financial support & 54.6 & 11.9 & 12.8 & 12.8 & 3.5 \\
\hline Access to loans. external financing & 54.5 & 15.9 & 10.5 & 11.0 & 3.0 \\
\hline $\begin{array}{l}\text { Bureaucraticprocedures } \\
\text { (includinglicensing) }\end{array}$ & 61.5 & 9.1 & 11.4 & 10.5 & 2.0 \\
\hline $\begin{array}{l}\text { Control and inspections } \\
\text { (administrative barriers) }\end{array}$ & 47.6 & 16.7 & 16.6 & 10.8 & 3.1 \\
\hline Terms of use of borrowed funds & 57.1 & 17.2 & 8.6 & 8.4 & 2.6 \\
\hline Imperfectlegislation & 65.0 & 9.3 & 10.3 & 7.6 & 2.4 \\
\hline Corruption & 70.2 & 11.7 & 5.3 & 4.7 & 2.2 \\
\hline Lack of systematic support work & 60.5 & 9.9 & 13.8 & 7.7 & 2.6 \\
\hline Attracting investors & 78.2 & 7.3 & 4.0 & 1.7 & 1.6 \\
\hline Interactionwithauthorities & 70.2 & 15.8 & 4.8 & 2.6 & 1.1 \\
\hline Weakinformationsupport & 71.7 & 11.8 & 6.2 & 2.7 & 1.7 \\
\hline Interactionwithsuppliers & 74.4 & 12.8 & 5.1 & 1.5 & 0.5 \\
\hline
\end{tabular}

As can be seen from the table, the following factors have the most significant influence limiting the development of SMEs in the agro-industrial complex:

- Difficult access to loans, external financing (a factor noted by $14.0 \%$ of enterprises);

- lack of own funds for business development (25.3\%);

- taxation $(31.0 \%)$

- strong competitors (17.0\%), etc.

\section{Discussion}

It is difficult to disagree with the opinion of Vito Tanzi that "a small number of welladministered universal programs can replace numerous existing programs, while eliminating financial risks and sources of uncertainty. Of course, this approach will require a tax revenue increase. However, at the same time, it will allow to avoid excessive complexity inherent in existing taxation systems and budget programs "[24, p.30]. Alongsidethe government support measures, it is necessary to develop infrastructure institutions on a paid basis. To develop the market ensuring economic security fundamentals, we propose to create a "Business Center for Small and Medium Enterprises" in three main centers of the Orenburg Region: Orenburg, Orsk, Buzuluk. The directions of their activities are determined by the problems facing small businesses in the appropriate districts of the region:

- implementation of federal, regional, industry and municipal programs for the development and support of small business, demonopolization of the economy, development of competition;

- carrying out activities aimed at attracting and efficient use of funds of domestic and foreign investors;

- training and professional development of entrepreneurs and managers, bank loan specialists;

- information and analytical, advertising and publishing activities;

- organization of experience exchange, cooperation with concerned national and international organizations, scientists and entrepreneurs. 
Thanks to the creation and functioning of the "Business Center for Small and MediumSized Enterprises," the small business of the city will be able to strengthen market relations; to form the basis of the middle class, which is the guarantor of social and political stability; to solve the problem of improving the efficiency of their own work by attracting enterprising, socially active people who are able to realize their abilities and ensure a decent standard of living for the family; promptly and adequately respond to fluctuations in consumer demand and changes in economic conditions; provide the consumer with a sufficient level of competition in the market environment.

Today, solving the problems of small business development, due to the fact that various groups of small businesses are beginners, which develop and work steadily, have their own interests and difficulties, requires the application of the principles of a differentiated approach to support different categories of small businesses.

Based on the identified needs of various groups of entrepreneurs, we propose to include 4 departments in the organizational structure of the Business Center: the Department of Economic Analysis and Marketing; Department of Additional Professional Education; Department of Business Information and Legal Support of Business Processes; Information Technology Implementation Department.

The differences in the schemes of the Center services providedto small businesses are due to the difference in their geographical location, the possibility of an entrepreneur personally visit the Center and the specific of the service itself.

Faculty of Economics of the Agricultural University together with the Regional Fund for Entrepreneurship Support held seminars with entrepreneurs in the districts of the Orenburg region. The results of the training seminars for small businesses in 16 municipalities of the Orenburg region let us suggest that there is almost complete absence of systemic support for small businesses in most municipalities of the region (except the large cities of Orenburg and Orsk) and the great demandin economic security.

The anti-crisis measures currently being implemented in the Orenburg Region connected with the support and development of entrepreneurship are certainly useful and necessary. However, the inherent potential of their effectiveness is not always realizedto full extend due to the fact that chosen implementation mechanism is not optimal. The opinion of the authorsA. I. Pilipenko; V. I. Dikhtiar; N. M. Baranova about the necessityof personalization of funding deserves attention[9]. So the funds allocated for training are spent on the maintenance of a large number of structures that do not provide educational services, but are intermediaries. Amounts disproportionate to the quality performance needs reach real executors.

\section{Conclusions}

To solve these problems, we propose to create a system of work with the novice subjects of small and medium-size enterprises in rural areas in the municipalities of the Orenburg region by the phased (3 years) formation of a network of self-supporting representations of the "Business Center" initially in 3 cities, covering all 43 municipalities of the region, and then by the opening of representative offices in each district.

It will make possible to implement on the basis of these representative offices a system of state support for start-up entrepreneurship, which includes financial (providing microloans and grants to start own business), educational (conducting training seminars and trainings) and information (advising on business activities) components.

The main function of these representative offices will be the implementation of two programs:

- $\quad$ ensuring the economic security of SMEs; 
- training for those who wish to start their own business, as well as for beginners of small and medium-size enterprises, the basics and specifics of running a successful business in modern conditions, with the possible subsequent granting the entrepreneurs who have successfully completed training for creating and conducting their own business (through issuing recommendations to such SMEs to receive a grant).

In the Orenburg region the Presidential program for training and retraining of managerial staff has been working for a long period of time, thanks to which many entrepreneurs have got the opportunity to obtain the necessary knowledge and ensure the sustainable development of their business. We believe that revival of such training and retraining program for entrepreneurs and people interacting with them in such areas of education as ensuring the economic security of business, tools for effective business, legal support of entrepreneurial activity, etc. would provide significant impetus for the development of both the SMEs themselves and the institutions for ensuring their economic security. Overcoming constraints is possible only with the direct interest of all participants to ensure economic security, namely, small business entities, government agencies, and support institutions.

\section{References}

1. S. Bareiko, National Security 5, 80-88 (2019) doi:10.7256/2454-0668.2019.5.30892

2. N. Kostini, S. Jaja Raharja, International Journal of Economic Policy in Emerging Economies 12(2), 130-139 (2019) doi: 10.1504/IJEPEE.2019.099732

3. A. Wahyu Puspitasari, International Journal of Economic Policy in Emerging Economies 11(1/2), 3-11 (2018) doi: 10.1504/IJEPEE.2018.091033

4. D.S. Khairullov, U.A. Saipullaev, Mediterranean Journal of Social Sciences 12, $177-$ 182 (2014) doi: 10.5901/mjss.2014.v5n12p177

5. M. Rund, C. Colins, W. Ton, Transfer. European Review of Labour and Research 20(5), 99-114 (2014) doi: 10.1177/ 1024258913514361

6. M. Panasyuk, L. Safiullin, I. Pryadko, T. Anopchenko, World applied sciences journal 27(13), 140-144 (2013) doi: 10.5829/idosi.wasj.2013.27.emf.29

7. D. Strang Kenneth, Z. Sun, Annals of Data Science 1, 1-17 (2017) doi: https://doi.org/10.1007/s40745-016-0096-6

8. Y. Nam, Y. Lee, S. Mcmahon, M. Sherraden, The Journal of consumer affairs 50(3), 611-637 (2015) doi:10.1111/joca.12078

9. A. Pilipenko, V. Dikhtiar, N. Baranova, Journal of Economic Policy in Emerging Economies 12, 85-99 (2019) doi: 10.1504/IJEPEE.2019.098703

10. V. Stukach, G. Saparova, G. Sultanova, S. Saginova, Economy of Region 15(1), 561575 (2019) doi:10.17059/2019-2-19

11. Law of the Orenburg Region dated November 17, 1997 No. 193/61-OZ

12. Order of the Head of the Administration of the Orenburg Region dated May 23, 2002 No. 256-r

13. Law of the Orenburg Region dated September 29, 2009 No. 3118/691-1U-OZ

14. Data on statistical tax reporting forms, https://www.nalog.ru/rn56/related_activities/statistics_and_analytics/forms/

15. Russian Federation Law of April 5, 2013 No. 44-FZ

16. Russian Federation Law of May 7, 2013 N 79-FZ

17. Russian Federation Law of July 23, 2013 No. 237- FZ 
18. Russian Federation Law N 292- FZ

19. Russian Federation Law of July 2, 2013 N 144- FZ

20. Russian Federation Law of June 28, 2013 N 134-FZ

21. S. Zemtsov, Y. Tsareva, Journal of the New Economic Association 37(1), 145-165 (2018)

22. H. Zhuang, H. Yin, M. Wang, J. Yang, Annals of economics and finance 20-2, 661689 (2019)

23. V. Tanzi, Economic Policy 13(5), 50-65 (2018) doi:10.18288/1994-5124-2018-5-5065

24. V. Gladkova, O. Repkina, Service in Russia and abroad, 7-16 (2016) doi:10.12737 / 19165 